\title{
Effects of Thyroid Hormone on Myocardial Adrenergic $\beta$-Receptor Responsiveness and Function during Late Gestation
}

\author{
EINAT BIRK, MICHAEL R. TYNDALL, LARS C. ERICKSON, ABRAHAM M. RUDOLPH, AND \\ JAMES M. ROBERTS
}

Cardiovascular Research Institute and Department of Pediatrics, University of California, San Francisco, California 94143

\begin{abstract}
To assess the effect of fetal hypothyroidism during late gestation on postnatal cardiovascular responsiveness, we measured heart rate and cardiac output responses to isoproterenol in newborn lambs. To evaluate the effect of such altered thyroid status on the development of $\beta$-adrenergic signaling cascade, we measured myocardial $\beta$-adrenergic receptor concentration and affinity, guanine nucleotide regulatory protein density, and adenylyl cyclase responsiveness. Twenty fetal lambs underwent either thyroidectomy and line placement or line placement alone at 128-130 d gestation. Five thyroidectomized and six control newborns were treated with isoproterenol, five thyroidectomized and four control newborns were killed upon delivery and tissue was obtained for biochemical studies, and four additional animals were delivered and killed at $126 \mathrm{~d}$ gestation and tissue was obtained for receptor analysis. Of the newborns treated with isoproterenol, the thyroidectomized lambs showed lower increase in heart rate and cardiac output compared with euthyroid newborns. Compared with the myocardium of normal newborns of similar gestation, the myocardium of the newborns who underwent fetal thyroidectomy failed to show the normal increase in $\beta$-adrenoceptors accompanied by reduction in $\beta$-adrenergicstimulated adenylate cyclase activity. These results suggest that near term, the normal development of ovine fetus myocardial $\beta$-adrenergic receptor is affected by thyroid hormones. (Pediatr Res 31: 468-473, 1992)
\end{abstract}

\section{Abbreviations}

AC, adenylyl cyclase

T3, triiodothyronine

CA, carotid artery

G-protein, guanine nucleotide regulatory protein

PA, pulmonary artery

FA, femoral artery

LA, left atrium

IVC, inferior vena cava

ICYP, iodocyanopindolol

$\mathrm{LV}$, left ventricle

ANOVA, analysis of variance

MHC, myosin heavy chain

The transformation from fetal to extrauterine life is associated with major respiratory, metabolic, and circulatory changes. The

Received January 3, 1991; accepted January 9, 1992.

Correspondence and reprint requests: James M. Roberts, M.D., Professor, Dept. of Obstetrics, Gynecology \& Reproductive Sciences, Senior Staff, Cardiovascular Research Institute, University of California, San Francisco, Box 0550, HSE 1462, San Francisco, CA 94143. expanded lungs substitute for the placenta in fulfilling the function of gas exchange, and the oxygen consumption by the body increases markedly, as does the cardiac output $(1,2)$. The mechanisms responsible for these changes are not fully understood.

Several studies have demonstrated hormonal changes during late gestation and immediately after birth, leading to speculation that such changes may affect maturation of the cardiovascular response mechanism as birth approaches. In sheep as well as other species, concentrations of thyroid hormones and corticosteroids gradually increase in the last $10-14 \mathrm{~d}$ of gestation (3-5), with an abrupt increase during the first hours of extrauterine life $(5,6)$. The increase in concentration of fetal plasma T3 is attributed both to a fall in its metabolic clearance rate and to a rise in production rate $(3,7)$. Another striking hormonal event is the increase in circulating levels of catecholamines during and immediately after parturition, as observed in lambs as well as human infants (8).

In a study testing the role of thyroid hormones in the postnatal increase in heart rate, cardiac output, and oxygen consumption, Breall et al. (9) observed that thyroidectomy of the sheep fetus $10-14 \mathrm{~d}$ before term blunted the normal increase in heart rate and cardiac output immediately after birth. However, thyroidectomy just before delivery did not affect normal postnatal changes. This suggested a prenatal influence of thyroid hormones in the latter days of gestation affecting cardiac responses.

Because studies in sheep and other species (10) have indicated that altered thyroid function can affect myocardial $\beta$-receptors, we wondered whether the effect of chronic fetal thyroidectomy on cardiac responses in the newborn may be mediated by inducing changes in the $\beta$-adrenergic signaling system. This signaling system activates a chain of events that affect myocardial chronotropy and inotropy.

We set out to explore 1 ) whether fetal thyroidectomy affects cardiovascular responsiveness to exogenous catecholamines, and 2 ) whether it affects components in the $\beta$-adrenergic signaling cascade, namely the receptor, the second messenger (cAMP), and the G-protein that links the two. We report that term newborn sheep, thyroidectomized at $129 \mathrm{~d}$ gestation, do not demonstrate the normal increase in cardiac output and heart rate in response to $\beta$-adrenergic stimulation, nor do they exhibit the normal increase in myocardial $\beta$-receptor concentration that occurs in late gestation. The reduced $\beta$-receptor concentration is accompanied by reduced $\beta$-adrenergic activation of adenylyl cyclase in myocardial membranes.

\section{MATERIALS AND METHODS}

Physiologic Studies. Ten pregnant ewes of known breeding dates were randomly assigned to two study groups. There was one set of twins, one of which was assigned to the treatment group and one which served as control. All animals $(n=11)$ 


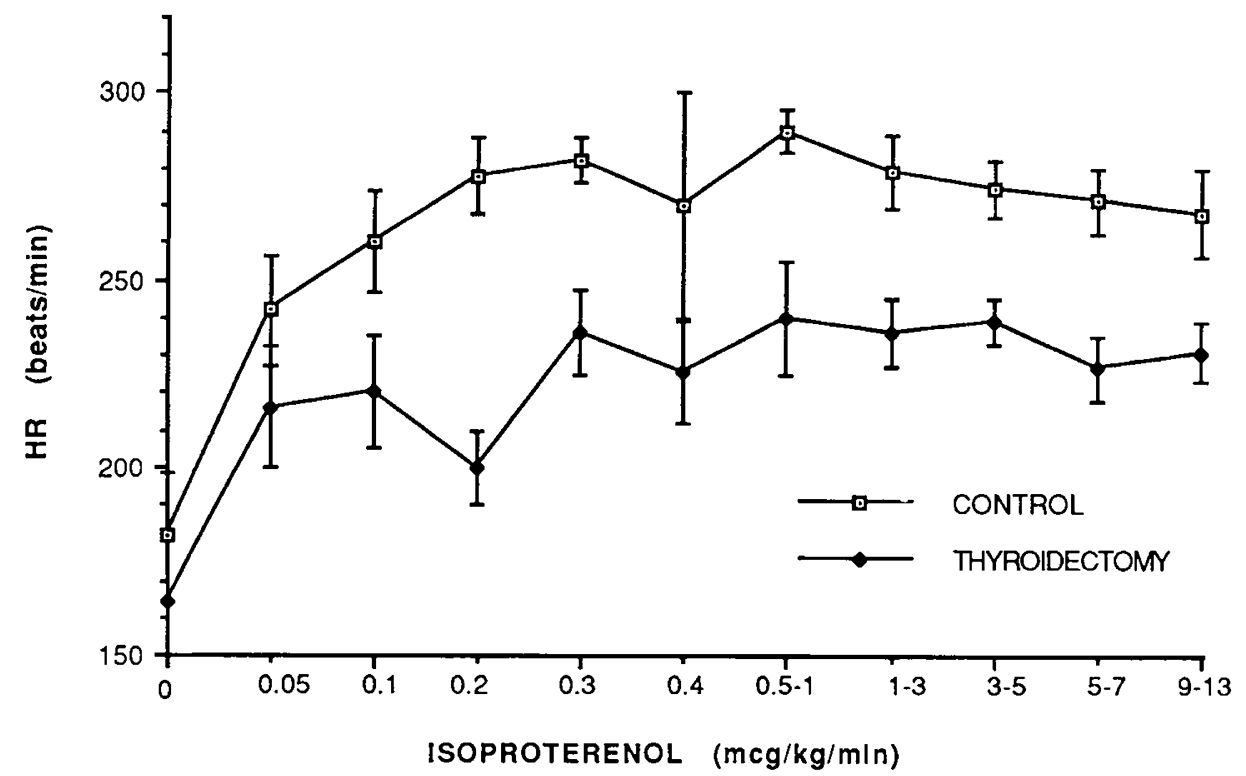

Fig. 1. Heart rate response to isoproterenol. Increasing doses of isoproterenol were administered i.v. to five thyroidectomized and six control newborn sheep. Data are presented as mean \pm SEM. Statistical analysis by ANOVA indicates a smaller increase in heart rate in response to isoproterenol in the thyroidectomized group $(p<0.01)$.

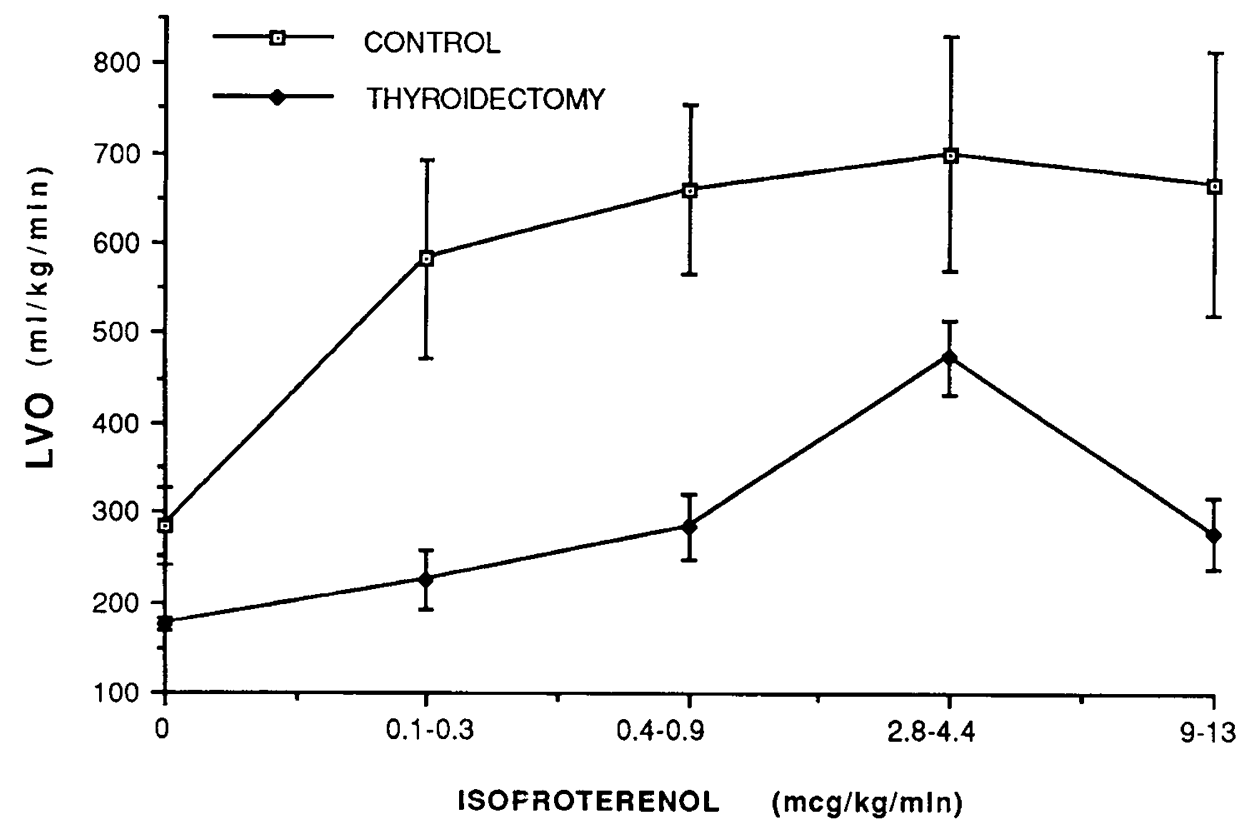

Fig. 2. LV output response to isoproterenol. Increasing doses of isoproterenol were administered i.v. to five thyroidectomized and six control newborn sheep. Data are presented as mean \pm SEM. Statistical analysis by ANOVA indicates a smaller increase in LV output in the thyroidectomized group $(p<0.01)$.

underwent fetal surgery at $\sim 129 \mathrm{~d}$ gestation for placement of catheters in the CA, PA, and FA, LA, and IVC. The treatment group $(n=5)$ also underwent total thyroidectomy.

Surgical preparation. Surgeries were performed after epidural anesthesia with $1 \%$ tetracaine $\mathrm{HCl}$ in the ewe, combined with intermittent i.v. administration of ketamine $\mathrm{HCl}$ to maintain sedation. All fetal surgical procedures were performed after local anesthesia with $0.25 \%$ tetracaine $\mathrm{HCl}$. Under strict aseptic conditions, the uterus was exposed through a midline laparotomy. As previously described (9), a hind limb was exposed through a small uterine incision, and polyvinyl catheters were inserted into the pedal artery and vein and advanced into the FA and IVC, respectively. A second uterine incision was made over the left chest, and a thoracotomy was performed in the fourth intercostal space; a catheter was inserted into the internal thoracic artery and advanced into the brachiocephalic trunk. Specially designed catheters were inserted into the LA and pulmonary trunk. In the animals that underwent thyroidectomy, the fetal head was exteriorized through the same uterine incision. After local anesthesia, a midline incision was performed extending from the larynx to the suprasternal region; two thyroid lobes as well as the isthmus were removed. The incision was closed, the head was returned into the amniotic cavity, and the uterine incision was sutured.

All animals were delivered by cesarean section at maturity as determined by total fetal plasma protein (11). Cesarean section was performed after epidural anesthesia with $1 \%$ tetracaine $\mathrm{HCl}$ in the ewe, combined with intermittent i.v. doses of ketamine $\mathrm{HCl}$ to maintain sedation. The average gestation on delivery was $138 \mathrm{~d}$ in the control and $139 \mathrm{~d}$ in the thyroidectomized group. After delivery, the animals were intubated and ventilated with 


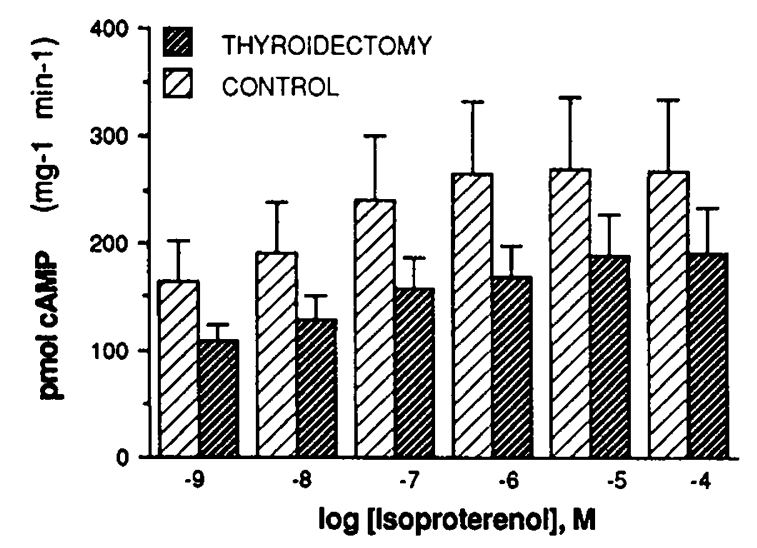

Fig. 3. Myocardial AC activity response to isoproterenol. Activity of myocardial AC was measured in the presence of increasing concentration of the $\beta$-adrenoceptor agonist isoproterenol in four thyroidectomized and five control newborn sheep. Data are presented as mean \pm SEM. Statistical analysis by ANOVA indicates a lower response in the thyroidectomized group $(p<0.05)$.

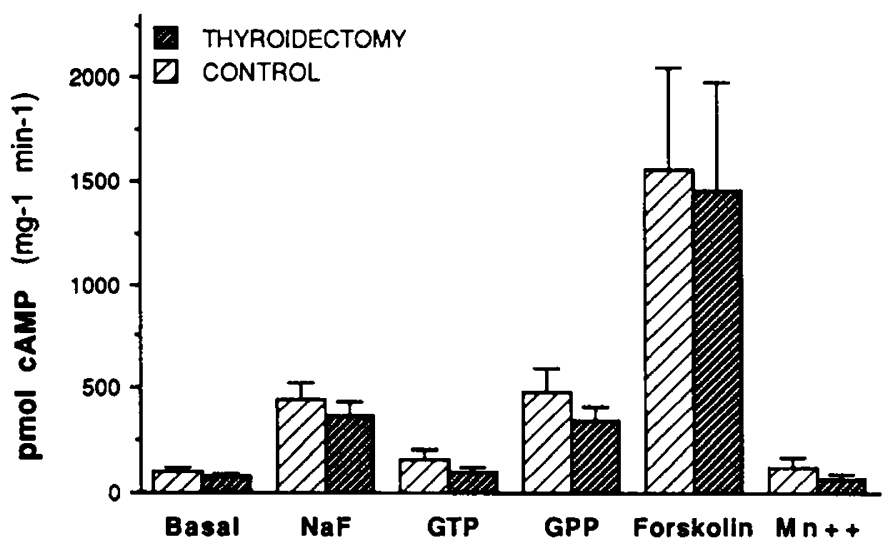

Fig. 4. The effect of fetal thyroidectomy on non- $\beta$-adrenoceptorstimulated AC activity. Basal and postreceptor-stimulated AC activity were measured in four thyroidectomized and five control newborn sheep. Data are presented as mean \pm SEM. Statistical analysis by ANOVA reveals no difference between the two groups.

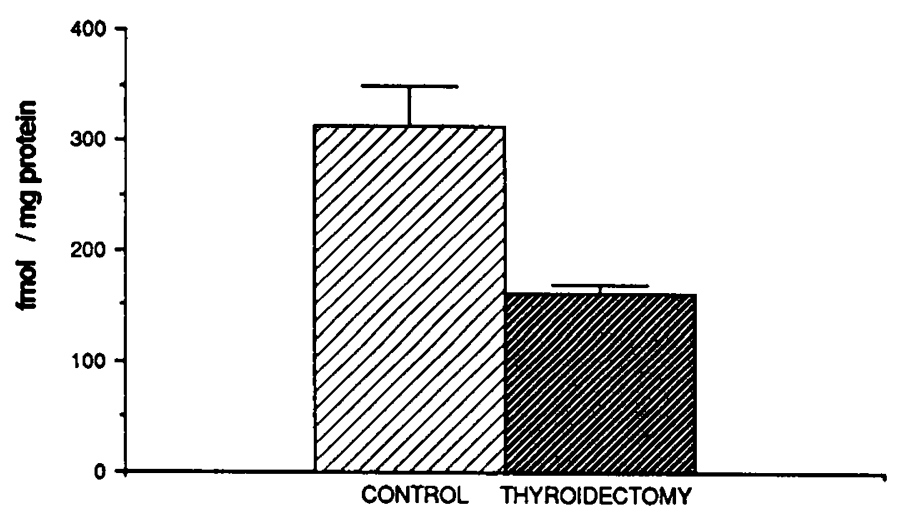

Fig. 5. The effect of fetal thyroidectomy on myocardial $\beta$-adrenoceptors. The concentration of $\beta$-adrenoceptors was determined in five thyroidectomized and four control newborn sheep using ICYP binding to membrane particulates. Data are presented as mean \pm SEM. Statistical analysis by paired $t$ test indicates a lower concentration of $\beta$-adrenoceptors in the thyroidectomized group $(p<0.01)$.

an oxygen and air mixture to maintain normal blood gases and $\mathrm{pH}$. They were dried and placed on a warming pad and under a surface heating lamp. Rectal temperature was monitored frequently and maintained at $38-39^{\circ} \mathrm{C}$. The CA, FA, and PA lines were connected to pressure transducers (Statham P23Db, Oxnard, CA) for continuous recording of heart rate and blood pressure on a Beckman direct-writing oscillograph. Once stabilized, baseline LV output and its distribution were measured using radionuclide-labeled microspheres (isotopes randomly selected from: ${ }^{57} \mathrm{Co},{ }^{51} \mathrm{Cr},{ }^{153} \mathrm{Gd},{ }^{114} \mathrm{In},{ }^{54} \mathrm{Mn},{ }^{95} \mathrm{Nb},{ }^{113} \mathrm{Sn},{ }^{85} \mathrm{Sr}$, or ${ }^{65} \mathrm{Zn}$; 3-M Company, St. Paul, MN; New England Nuclear, Boston, MA). The microspheres were injected into the LA, and arterial reference samples were withdrawn from the CA and FA catheters at a rate of $3.6 \mathrm{~mL} / \mathrm{min}$. The volume of blood withdrawn was replaced with equal volume of fetal donor blood or maternal blood. After determination of the baseline output, increasing doses of isoproterenol were infused to all animals via the IVC. Isoproterenol was administered at an initial dose of $0.05 \mu \mathrm{g} / \mathrm{kg} / \mathrm{min}$, which was increased in a stepwise fashion to a maximum of $\sim 13 \mu \mathrm{g} / \mathrm{kg} / \mathrm{min}$. The LV output, heart rate, and blood pressure were determined after each dose of isoproterenol once heart rate and blood pressure stabilized (heart rate and blood pressure were averaged over 1-min intervals). At the end of the procedure, the lambs were killed with an overdose of i.v. sodium pentobarbital. The quantification of the individual radionuclides in each organ was performed as described previously (12). Briefly, blood flow (Q) in each organ can be calculated by measuring the $\mathrm{cpm}$ of the injected radioisotope trapped in that organ, the $\mathrm{cpm}$ of that isotope in the reference arterial sample, and reference sample flow where $Q_{\text {organ }}=\mathrm{cpm}_{\text {organ }} / \mathrm{cpm}_{\text {reference }} \times$ $Q_{\text {reference. }}$ Because microsphere injections are performed in the LA, the quantification of blood flows in each tissue allows the calculation of $\mathrm{LV}$ output. Blood flows are expressed as $\mathrm{mL} / \mathrm{min} /$ kg tissue.

Biochemical Studies. Tissue. Heart tissue was obtained from three other groups of newborn lambs. Group I consisted of five animals thyroidectomized at $\sim 128 \mathrm{~d}$ of gestation. T3 levels were determined to assure complete thyroidectomy. The mean T3 value of this group was $0.1 \pm 0.1 \mathrm{ng} / \mathrm{mL}$ at delivery and did not change during the first $2 \mathrm{~h}$ of life. Group II included four animals that were operated upon at $\sim 130 \mathrm{~d}$ of gestation for intravascular line placement only. A third group of four animals was not operated upon; the animals were delivered at $126 \mathrm{~d}$ of gestation (the approximate age at which the study group was thyroidectomized) and killed immediately. All fetuses were delivered by cesarean section; groups I and II were delivered upon maturity as described above (average gestational age $138 \mathrm{~d}$ ) and then killed by i.v. overdose of sodium pentobarbital. The hearts were then excised, dissected into right and left ventricles, and immediately frozen at $-70^{\circ} \mathrm{C}$ until preparation of membrane particulates.

Membrane preparation. Partially purified membrane particulates of newborn sheep heart were prepared by different centrifugation. Thawed frozen heart tissue was dissected free of major blood vessels and epicardial fat. It was then weighed, placed in 4-mL ice-cold buffer (50 mM Tris and $1 \mathrm{mM}$ EDTA, $\mathrm{pH} 7.4$ ) per $\mathrm{g}$ of tissue, and homogenized with a Tekmar Tissumizer (Tekmar, Cincinnati, $\mathrm{OH}$ ). The homogenate was centrifuged at $1000 \times g$ for $15 \mathrm{~min}$, and the pellet was resuspended in the same buffer and centrifuged at $1000 \times g$ for $15 \mathrm{~min}$. The two lowspeed supernatants were combined and centrifuged at $29000 \times$ $g$ for $15 \mathrm{~min}$. The resulting pellet was washed and recentrifuged three times in $25 \mathrm{~mL}$ of cold buffer $(50 \mathrm{mM}$ Tris and $4 \mathrm{mM} \mathrm{Mg}$, $\mathrm{pH}$ 7.4). The final pellet was resuspended using a Potter-Elvehjem tissue homogenizer in $1 \mathrm{~mL}$ of Tris- $\mathrm{Mg}$ per $\mathrm{g}$ of tissue. Protein concentration was determined using the Bradford method with BSA as the standard. Aliquots of the membrane particulates were frozen in liquid nitrogen and stored at $-70^{\circ} \mathrm{C}$ until used.

$A C$ assay. $\mathrm{AC}$ activity was determined in triplicate using a modification of the method of Salomon et al. (13). The assay contained 30-60 $\mu \mathrm{g}$ of membrane protein, $50 \mathrm{mM} \mathrm{N}$-2-hydroxyethylpiperazine- $N^{\prime}$-2-ethanesulfonic acid, $4 \mathrm{mM} \mathrm{MgCl}, 0.2$ mM EGTA, $2 \mathrm{mM} \beta$-mercaptoethanol, $0.1 \mathrm{mg} / \mathrm{mL} \mathrm{BSA}, 10$ $\mathrm{mM}$ creatine phosphate, $10 \mathrm{U} / \mathrm{mL}$ creatine phosphokinase, 0.4 


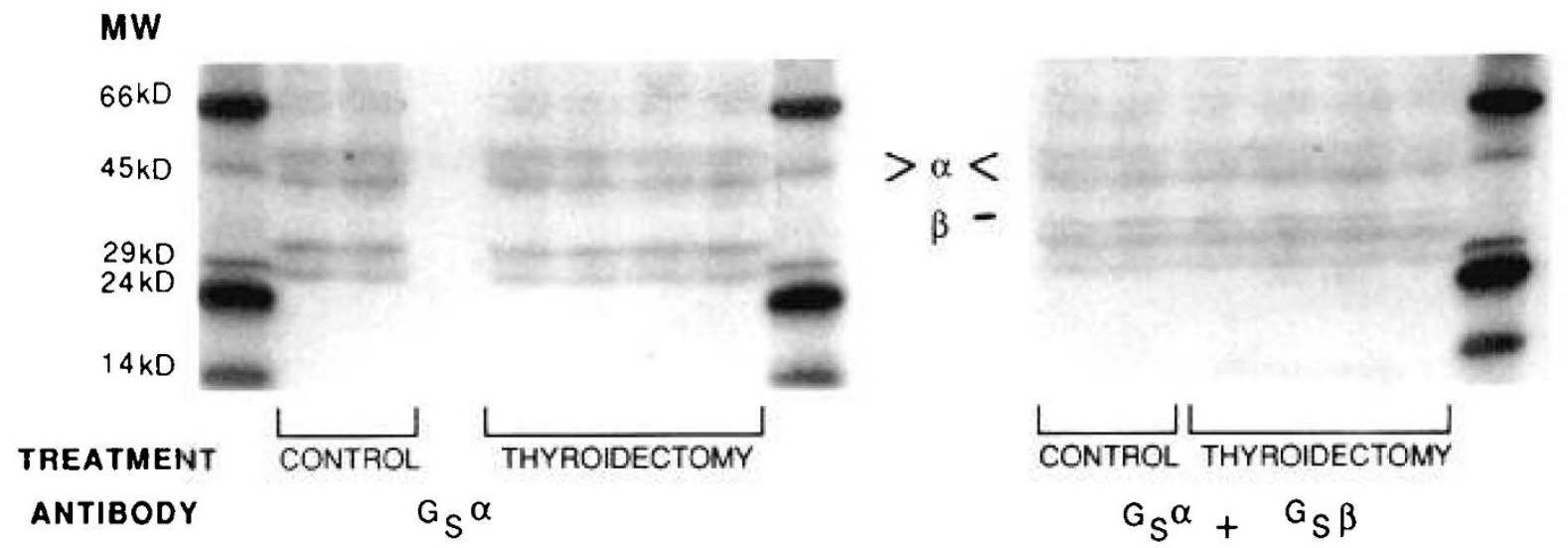

Fig. 6. Western blot analysis of G-protein subunits. Relative concentrations of the stimulatory G-protein $\alpha$-and $\beta$-subunits were determined in thyroidectomized and control myocardium using immunoblotting technique. The comparison of the corresponding bands by laser densitometry reveals no difference between the two groups. An empty lane was left between groups on the gel tested for the $\alpha$-subunit.

mM ATP, $1 \mathrm{mM}$ cAMP, $30000 \mathrm{cpm}\left[{ }^{3} \mathrm{H}\right] \mathrm{cAMP}, 1000000 \mathrm{cpm}$ $\left.{ }^{32} \mathrm{P}\right] \mathrm{ATP}$, guanosine triphosphate, and effectors. The reaction mix was incubated at $37^{\circ} \mathrm{C}$ for $10 \mathrm{~min}$. cAMP was separated from ATP by chromatography on Dowex and Alumina columns.

Binding Studies. Saturation analysis to determine $\beta$-receptor concentration and affinity was performed as follows. Cardiac membrane particulates $(40-80 \mu \mathrm{g}$ of protein) were incubated at $30^{\circ} \mathrm{C}$ for $120 \mathrm{~min}$ in a $0.25-\mathrm{mL}$ volume containing $50 \mathrm{mM}$ Tris and $4 \mathrm{mM} \mathrm{MgCl}_{2}$ buffer (pH 7.4), $1 \mathrm{mM}$ ascorbic acid, $6-400$ pM ${ }^{125} \mathrm{ICYP}$, both with and without $100 \mu \mathrm{M}$ isoproterenol. At the end of the incubation, $5 \mathrm{~mL}$ of ice-cold buffer were added, and the samples were filtered through Whatman GF/C glass fiber filters to separate free and bound ${ }^{125}$ ICYP. After three $5-\mathrm{mL}$ washes, the filters were dried and counted in a gamma counter (Beckman). Specific binding, determined as binding prevented by $100 \mathrm{mM}$ isoproterenol, was analyzed as a function of free ligand using an iterative nonlinear curve fitting program (14).

$G$-protein immunoblotting. Myocardial membrane particulates $(\sim 100 \mu \mathrm{g}$ protein/lane) were separated by SDS-PAGE $(12 \%$ acrylamide). The separated proteins were then transferred from the gel to nitrocellulose paper using an electroblotting apparatus (Bio-Rad, Richmond, CA) operated at a constant current for 16 h. The nitrocellulose was then washed with PBS containing Tween followed by PBS + Tween + india ink (to stain proteins on the blot). The blot was then incubated with rabbit antisera to anti- $\alpha-\mathrm{i}, \alpha-\mathrm{S}$ and $\beta-\gamma$ subunits (Generously provided by Dr. S. Mumby, University of Texas, Southwestern Dallas) at room temperature for $1 \mathrm{~h}$. After three washes with PBS-Tween, the blots were incubated with ${ }^{125} \mathrm{I}$-labeled goat anti-rabbit $\mathrm{F}(\mathrm{ab})(\sim 1$ $\times 10^{6} \mathrm{cpm} / \mathrm{mL}$ ) for $1 \mathrm{~h}$ in room temperature. The blot was then washed three more times and allowed to air dry. Autoradiography of the dried blot was performed, and the relative concentrations of the different subunits were determined using laser densitometry stimulation.

Statistical analysis. The data are presented as mean values \pm SEM. Statistical significance of differences was tested by the unpaired $t$ test or, when more than two comparisons were made, by ANOVA. A confidence level of $95 \%$ was the criterion for significance.

\section{RESULTS}

Cardiovascular response to $\beta$-adrenergic stimulation. Baseline heart rate did not differ between treatment groups by $t$ test $(164$ $\pm 16 \mathrm{bpm}$ in the thyroidectomized lambs versus $182 \pm 17 \mathrm{bpm}$ in the control, $p=0.2$ ). However, the increase in heart rate in response to increasing doses of isoproterenol (ranging from 0.05 to $13 \mu \mathrm{g} / \mathrm{kg} / \mathrm{min}$ ) was significantly less in the thyroidectomized group (ANOVA $p<0.01$, Fig. 1). Moreover, the maximal heart rate achieved with $\beta$-receptor stimulation (i.e. the maximal heart rate achieved by each animal, regardless of the isoproterenol dose needed to induce it) was significantly lower in the thyroidectomized lambs at $240 \pm 9 \mathrm{bpm}$ versus $296 \pm 6 \mathrm{bpm}$ in the control group $(p<0.001)$.

The baseline LV output was not significantly different in the thyroidectomized and control groups $(181 \pm 9$ versus $257 \pm 50$ $\mathrm{mL} / \mathrm{kg} / \mathrm{min}$ in the control; $p=0.1)$. However, the dose-dependent isoproterenol-induced increase in LV output was significantly lower in the thyroidectomized newborns (ANOVA $p<0.01$, Fig. 2). Similarly, the maximal isoproterenol-induced LV output (i.e. the maximal LV output achieved by each animal, regardless of the isoproterenol dose needed to induce it) was significantly lower in the thyroidectomized animals $[370 \pm 66$ versus $752 \pm$ $108 \mathrm{~mL} / \mathrm{kg} / \mathrm{min}$ (mean $\pm \mathrm{SEM}$ ); $p=0.01]$. The mean arterial blood pressure was comparable in both groups throughout the experiment.

$A C$ activity. Activity was measured in partially purified myocardial membrane particulates. The basal AC activity was similar in thyroidectomized and control newborns. However, the AC activity in response to the $\beta$-adrenoceptor agonist isoproterenol was lower (ANOVA $p=0.04$ ) in the thyroidectomized group in a dose-dependent manner (Fig. 3). The concentration of isoproterenol resulting in half the maximal effect did not differ in the two groups. Basal AC activity as well as its postreceptor AC activation by guanine nucleotides, forskolin, and $\mathrm{Mn}^{++}$were not altered by the treatment (Fig. 4).

$\beta$-receptor concentration. Binding of the specific $\beta$-adrenoceptor antagonist ICYP in myocardial membrane particulates was saturable and of high affinity. The $\beta$-receptor concentration was $161 \pm 8 \mathrm{fmol} / \mathrm{mg}$ protein in the thyroidectomized group and $313 \pm 36 \mathrm{fmol} / \mathrm{mg}$ in the term control animals $(p=0.001)$ (Fig. $5)$. The $\beta$-adrenoceptor concentration in a premature control group (gestational age $126 \pm 1 \mathrm{~d}$ ) was $142 \pm 13 \mathrm{fmol} / \mathrm{mg}$, i.e. not different than in the thyroidectomized animals and significantly lower than in the term control group. The $k_{d}$ of ICYP did not vary with gestational age and was not affected by thyroidectomy (mean value $157 \mathrm{pM}$, range $140-210 \mathrm{pM}$ ).

$G$-protein determination. Immunoblotting analysis of the $\mathrm{G}_{\mathrm{S}} \alpha$ and $\beta-\gamma$ subunits was followed by autoradiography. The densities of the 45000 and 35000 molecular weight bands were compared using a laser densitometer. No differences were identified between the treatment groups (Fig. 6).

\section{DISCUSSION}

Previous studies have shown that fetal thyroidectomy performed 10-14 d before term prevents the normal neonatal increase in cardiac output. Our study demonstrates that this is accompanied by a reduction in responsiveness to $\beta$-adrenergic stimulation: both heart rate and cardiac output response to 
isoproterenol were reduced in thyroidectomized animals. Although maximal heart rate was lower by only $\sim 10 \%$ in the thyroidectomized newborns, the maximal LV output in this group was $\sim 50 \%$ lower. At the same time, the mean arterial blood pressure was comparable in both groups. These findings indicate that the decreased ability of $\beta$-receptor stimulation to increase LV output in the thyroidectomized newborns is not fully explained by their inability to achieve a heart rate similar to control animals. The similar blood pressure in both groups, together with a larger increase in cardiac output in the control animals, indicates a more pronounced decrease in systemic vascular resistance in this latter group. However, it has been shown that lowering systemic vascular resistance with nitroprusside infusion does not lead to a significant increase in cardiac output in newborn lambs (15). Thus, the greater increase in cardiac output in the control newborns during isoproterenol infusion likely reflects greater inotropic stimulation rather than decreased afterload. Because preload was not closely monitored in all animals, the relative role of contractility cannot be determined.

We examined the components of the $\beta$-receptor $\mathrm{AC}$ response cascade to attempt to explain the reduced physiologic $\beta$-adrenergic responsiveness with thyroidectomy. We observed that thyroidectomy resulted in a $50 \%$ reduction in the number of myocardial $\beta$-adrenoceptors. This lower receptor concentration was associated with a decreased activation of $\mathrm{AC}$ by isoproterenol. However, AC activation by effectors acting beyond the receptor was not decreased. Such postreceptor activators included the Gprotein stimulators $\mathrm{NaF}$, guanosine triphosphate, and guanosine 5 'imido-diphosphate as well as the catalytic component stimulators $\mathrm{Mn}^{++}$and forskolin. Thus, it appears likely that the reduction of $\beta$-receptor-stimulated AC is explained by the reduced $\beta$ receptor concentration. This hypothesis is further supported by the similar concentration of G-protein subunits identified by Western blotting of myocardial membranes from the differently treated animals.

To determine whether the lack of thyroid hormones during late gestation prevented an increase in the $\beta$-receptor concentration or actually led to a decrease, we determined the receptor concentration in a control group killed at the gestational age at which thyroidectomy was performed. The receptor concentration in this group was significantly lower than in term controls and similar to that of the term thyroidectomized group. It therefore appears that the lack of thyroid hormones prevented the normal increase in the $\beta$-adrenoceptor concentration during late gestation.

The effect of thyroid hormones on the myocardial adrenergic receptor has been examined extensively. Most studies were performed in rat heart and dealt with hyperthyroid state. A significant increase in $\beta$-receptors with a proportional increase in isoproterenol-responsive $\mathrm{AC}$ activity $(16,17)$ was reported with excess thyroid hormone. Although there is less information addressing the influence of the hypothyroid state, most investigators report a decrease in $\beta$-receptor concentration (30-50\%) in myocardium of hypothyroid rats without a change in the affinity of isoproterenol. Only a few studies have tested the modulation of adenylate cyclase activity by thyroid hormones. One study demonstrated concurrent decrease in $\beta$-receptor number and isoproterenol-responsive AC activity (18). The mechanism by which thyroid hormone affects the concentration of myocardial $\beta$-receptors is unclear, but presumably involves the synthesis of a new receptor.

An additional possible explanation for the changes in contractility is the regulation of MHC gene expression by thyroid hormone. It has been shown that thyroid hormone regulates the expression of ventricular myosin isoenzymes by stimulating synthesis of $\alpha$-MHC and inhibiting that of $\beta$-MHC (19-21). It has also been shown that in primary culture of fetal rat myocytes, the absence of T3 results in the predominant expression of $\beta$ MHC. Such an effect will lead to an increase in the myosin isoforms that have lower ATPase activity and to a decrease in the highest ATPase activity isoform (22). Because myosin ATPase activity closely correlates with myocardial speed of contraction, such changes may indicate the ability of thyroid hormone to affect contractility via a direct effect on the contractile apparatus.

Our findings do not agree with similar studies done in sheep by Padbury et al. (23). In their study, fetal heart and lung $\beta$ receptor concentration were not affected by either hypothyroid or hyperthyroid state. An important difference between their study and ours is the timing of the experiment. Although they performed the fetal thyroidectomy at $\sim 119 \mathrm{~d}$ of gestation and killed the animals $8 \mathrm{~d}$ later, we thyroidectomized the fetuses approximately $10 \mathrm{~d}$ later, i.e. well within the period in which fetal thyroid hormones are reported to increase, and studied them near term. The duration of the induced fetal hypothyroidism was similar in both studies. Conceivably, other mechanisms or hormonal changes occurring during the terminal part of gestation alter fetal responsiveness to thyroid hormones and/or act directly on the myocardial $\beta$-receptor cascade. For example, adrenal steroids show a similar pattern of ontogenic development to thyroid hormone, and also affect myocardial basal and $\beta$ receptor-mediated AC activity. Sundaresan and Banerjee (24) found that myocardium of animals that underwent both thyroidectomy and adrenalectomy had reduced basal and isoproterenolstimulated AC activity compared with myocardium of animals that underwent thyroidectomy alone. The Padbury study was executed earlier in gestation, when cortisol concentrations are lower than at the gestational age at which our study was performed; this might explain the difference in results.

Our findings suggest that the prenatal increase in thyroid hormones is required for the normal increase in myocardial $\beta$ adrenoceptor concentration, which in turn potentiates the ability of the heart to increase its output in response to the major increase in circulating catecholamines that occurs at birth (8).

\section{REFERENCES}

1. Lister G, Walter TK, Versmold HT, Dallman PR, Rudolph AM 1979 Oxygen delivery in lambs: cardiovascular and hematologic development. Am J Physiol 237:H668-H675

2. Rudolph AM, Heymann MA 1970 Circulatory changes during growth in the fetal lamb. Circ Res 26:289-299

3. Fraser M, Liggins CG 1988 Thyroid hormone kinetics during late pregnancy in the ovine fetus. J Dev Physiol 10:461-471

4. Nwosu UC, Kaplan MM, Utiger RD, Delivoria-Papadopoulos M 1978 Surge of plasma triiodothyronine before birth in sheep. Am J Obstet Gynecol 132: 489-494

5. Devaskar UP, Devaskar SU, Sadiq HF, Chechani V 1986 Ontogeny of plasma free thyroxine and triiodothyronine concentrations during the perinatal period and maternofetal transfer of thyroid hormones in the rabbit. Dev Pharmacol Ther 9:115-123

6. Erenberg A, Phelps DL, Lam R, Fisher DA 1973 Total and free thyroid hormone concentrations in the neonatal period. Pediatrics 53:211-215

7. Wu SY, Klein AH, Chopra IJ, Fisher DA 1978 Alterations in tissue thyroxine5 -monodeiodinating activity in perinatal period. Endocrinology 103: 235-239

8. Padbury JF, Diakomanolis ES, Hobel CJ, Perelman A, Fisher DA 1981 Neonatal adaptation: sympatho-adrenal response to umbilical cord cutting. Pediatr Res 15:1483-1487

9. Breall JA, Rudolph AM, Heymann MA 1984 Role of thyroid hormone in postnatal circulatory and metabolic adjustments. $J$ Clin Invest 73 : $1418-1424$

10. Whitsett JA, Pollinger J, Matz S 1982 Beta-adrenergic receptors and catecholamine sensitive adenylate cyclase in developing rat ventricular myocardium: effect of thyroid status. Pediatr Res 16:463-469

11. Bland RD 1972 Cord-blood total protein level as a screening aid for the idiopathic respiratory-distress syndrome. N Engl J Med 287:9-13

12. Baer RW, Payne BA, Verrier ED, Vlahakes GJ, Molodowitch D, Uhlig PN, Hoffman JIE 1984 Increased number of myocardial blood flow measurements with radionuclide-labeled microspheres. Am J Physiol 246:H418-H434

13. Salomon Y, Londos C, Rodbell M 1974 A highly sensitive adenylate cyclase assay. Anal Biochem 58:541-548

14. Roberts JM 1986 Techniques for the direct examination of adrenergic receptors in developmental studies. In: Nathanielsz PW (ed) Animal Models in Fetal Medicine. Perinatology Press, Ithaca, NY, pp 187-269

15. Kuipers JRG, Sidi D, Heymann MA, Rudolph AM 1984 Effects of nitroprusside on cardiac function, blood flow distribution, and oxygen consumption in the concious young lamb. Pediatr Res 18:618-626 
16. Tse J, Wrenn RW, Kuo JF 1980 Thyroxine-induced changes in characteristics and activities of $\beta$-adrenergic receptors and adenosine $3^{\prime}, 5^{\prime}$-monophosphate and guanosine $3^{\prime}, 5^{\prime}$-monophosphate systems in the heart may be related to reputed catecholamine supersensitivity in hyperthyroidism. Endocrinology 107:6(abstr)

17. Krawietz W, Werdan K, Erdmann E 1982 Effects of thyroid status on $\beta$ adrenergic receptor, adenylate cyclase activity and guanine nucleotide regulatory protein in rat cardiac and erythrocyte membranes. Biochem Pharmacol 31:2463-2469

18. Ciaraldi TP, Marinetti GV 1978 Hormone action at the membrane level. VIII. Adrenergic receptors in rat hearts and adipocytes and their modulation by thyroxine. Biochim Biophys Acta 541:334-346

19. Lompré AM, Nadal-Ginard B, Mahdavi VJ 1984 Expression of the cardiac ventricular $\alpha$ - and $\beta$-myosin heavy chain genes is developmentally and hormonally regulated. J Biol Chem 259:6437-6446

20. Everett AW, Sinha AM, Umeda P, Jakovcic S, Rabinowitz M, Zak R 1984
Regulation of myosin synthesis by thyroid hormone: relative change in the $\alpha-$ and $\beta$-myosin heavy chain mRNA levels in rabbit heart. Biochemistry 23 : 1596-1599

21. Gustafson TA, Markham BE, Morkin E 1986 Effects of thyroid hormone on $\alpha$-actin and myosin heavy chain gene expression in cardiac and skeletal muscles of the rat: measurement of mRNA content using synthetic oligonucleotide probes. Circ Res 59:194-201

22. Gustafson TA, Bahl JJ, Markham BE, Roeske WR, Morkin E 1987 Hormonal regulation of myosin heavy chain and $\alpha$-actin gene expression in cultured fetal rat heart myocytes. J Biol Chem 262:13316-13322

23. Padbury JF, Klein AH, Polk DH, Lam RW 1986 Effect of thyroid status on lung and heart beta-adrenergic receptors in fetal and newborn sheep. Dev Pharmacol Ther 9:44-53

24. Sundaresan PR, Banerjee SP 1987 Differential regulation of beta-adrenergic receptor-coupled adenylate cyclase by thyroid hormones in rat liver and heart: possible role of corticosteroids. Horm Res 27:109-118 